Journal of Engineering and Applied Sciences 15 (4): 970-975, 2020

ISSN: $1816-949 \mathrm{X}$

(C) Medwell Journals, 2020

\title{
Smart City Concept (SCC) to Ensure Transparency in Public Utilities and Services Sectors of Emerging Countries
}

\author{
Afaq Hyder Chohan and Jihad Awad \\ Department of Architecture, Ajman University, Ajman, UAE
}

\begin{abstract}
In contemporary time the Smart City Concept (SCC) is considered as a viable solution to boost the efficiency of city operations and services concerning with common citizens in many developed countries. The key function of Smart City Concept (SCC) is to adapt or replace the traditional system of city management system with ICT based technology. This study developed the criteria that services sector of emerging countries is plagued with corruption and adaption of ICT technology will ensure transparency and improve the functions and management of a city. These criteria defined opportunities that would facilitate and permit rapid graphic interaction among common citizens, governments, businesses and several agencies. This study found that corrupt practices in public sectors of emerging countries has affected the common citizen in these countries. Moreover, study has examined the need of adopting (SCC-ICT) tool to control the malafide practices in public sectors of emerging countries. In addition, also established that (SCC-ICT) would facilitate the citizens to get the public sector services in transparent and timely manner. Urban governance, organization, transportation, energy and revenue collection are considered as key factors of city management and this study has presented a model to show the possibilities adapting the new ICT technologies in addressing these urban challenges. The study is divide into three parts; first part of this study presented the definition and general understanding of smart city concept and information communication technology. In second part, highlighted the facets of corruption in public sector of emerging countries and its implications on citizens. Whereas in third part of study has appraised the need of ICT system and proposed a model to ensure transparency and minimize the corruption in services and utilities sectors of emerging countries.
\end{abstract}

Key words: Smart city concept Information Communication Technology (ICT), corruption in public utilities, services sector, transportation, technology, corruption

\section{INTRODUCTION}

This review study is compromises of observations based on field study, literature review and participation. Study echoes three diverse themes related to poor performance of public sector offices in emerging countries. First, despite media facilitated campaign and intellectual discussions about corruption over past few years there is no notable reduction in levels of corruption. It is growing steadily and there is no agreement about how to stop the malafide practices and corruption in emerging countries. Second, effective and time lined legislation is not available to handle corruption cases, particularly white color crime. Third, the ability of corrupt officials in emerging countries to substitute to alternate methods of corruption and otherwise adapt to policy changes. Fourth, highlighting the need of using (SSC-ICT) tool in government information systems.

During last decade, users of ICT have increased drastically and resulted in quick development, many business promoting and services sectors are successfully using the ICT for example; traveling, tourism, motor vehicle registration, renewal, toll tax, police, revenue collectionare widely using the mobile application to facilitate their customers. It is worth noticing that mobile application are very popular in common people and its simple use hassur passed conventional software engineering processes (Awad et al., 2017).

This study consider that, opportunities for corruption can be reduced in emerging countries by avoiding personal contact through the use of ICT/online service delivery and by eliminating unnecessary bureaucracy (Fellows et al., 2016). Because this is an only viable way, through which citizens of emerging country can get there work done in public sector offices, without taking the tax of bribes, delays and humiliation.

According to Khan (2016), private interest of service men provokes corruption and they break the law in pursuit of their mare interests. The nexus of corruption is very strong in services sector of emerging countries, thus, officials interpret the laws in different ways thus results diverse consequences. The rising level of corruption is adversely affecting the citizens study of Hunt (2007) asserts that, common people in emerging countries spend substantial amount to pay bribes and it adds up layers of adverse impact on their household budget and savings. In

Corresponding Author: Afaq Hyder Chohan, Department of Architecture, Ajman University, Ajman, UAE 
other words, it can be added that corruption is a supplementary cost on the victims of misfortune in emerging countries.

Emerging countries are inundate by high levels of corruption and there are several reasons and repercussions of corruption in these regions. There are several causes of corruption such as; high inflation, no or low public services (hospital, housing, education etc.). The causes of corruption are tangible but the implications of corruption is conjectural and its affects are far reaching. For example in addition to weaker social bonding, corruption corrodesthe people belief in government and prevailing law. This conjectural phenomenon causes violence, crime, anger and fragment society. The amalgamation of such conditions results hampersininvestment, economic growth and jobs. However, corruption can be defied through proper planning of financial and human resources (WB., 2018).

Evidences from survey study suggests that corruption is widespread in the world and more prevalent in emerging countries than in rich ones (Svensson, 2005). This study is further supported by empirical studies of WB. (2018) which mention that the lower income people pay the highest percentage of their income in bribes. For example in Paraguay, the poor pay $12.6 \%$ of their income to bribes while high-income households pay $6.4 \%$.

Taking account of corruption in emerging economies of emerging countries by Asia, Zamir (2018) added that, Bangladesh routinely finds itself among the list of the most corrupt countries of the world. Study further revel that, bribery, rent-seeking and inappropriate use of government funds, long delays in service performance, pilferage, irresponsible conduct from government officials are facets of corruption in Bangladesh. In addition, governmental departments associated with water supply, electricity, gas supply, education, waste disposal, health, transportation, issue of passports and maintenance of land records are also vulnerable to corruption (Desai, 2018).

Cited the study of Transparency International and mentioned that india is listed in most corrupt countries in the world. Pakistan is also facing high level of corruption in both private and public sectors; Pakistan's with massive population, multi-linguistic and racial society, diverse cultures, slow economy and limited employment opportunities have stemmed in extreme competition for the work placements in the public and private sectors. This situation caused cross racial and linguistic pulls, enfeebled professional conduct in society, that eventually upshot corruption in both public and private bureaucracy (Tanzi, 1995).

Another study by Khan (2016) mention that, corruption in Pakistan is so common that it took the shape of parallel governing system. Therefore, normal citizens of Pakistan have accepted it as a way of life because corruption is deep rooted and relevant public officials are reluctant to this phenomenon, thus most of victims do not even report it. In addition, the long and time-consuming reporting procedure also discourages people to report the corruption. Thanks to smart mobile devices and social media and that allows people to record the incident and broadcast to get the attention of highest rank of judiciary and public office.

According to TI. (2016) Africa is also affected by corruption, majority of population in Sub-Saharan Africa have paid bribes to get their work done. People are forced to pay bribes to get access to the basic services. This form of corruption promotes and increases poverty, violence, crimes and elimination. Majority of Africans regions are suffering from deprivation of basic needs like food, sanitation, health, education, housing, potable water, while corrupt officials and individuals with backing of governmental support enjoy aextravagant life (Ugaz, 2015).

Discussion above has established that corruption is overwhelming in emerging countries particularly utilities and services are highly affected in public sector. Studies revealed that virtual interface in public office can minimize the level of corruption in these sectors. Moreover, ICT platformscan help common people to manage their needs related to public sector services. Therefore, there is a need is to develop the reliable, fast and suitable information communication technology based service platform to provide transparent and corruption free service. Because the common people or end user have limited or no option to say no to corruption or to ascertain the transparency in utility and services sector of emerging countries. Thus, aslot is present to develop an ICT based system to help and educate common people about problems and issues they are facing in utilities and services sector.

\section{FACETS OF CORRUPTIONS IN PUBLIC SERVICES/UTILITY SECTOR OF EMERGING COUNTRIES}

In general corruption in emerging countries are affecting the people life in these regions, however, services and utility sectors of government are most notable in this regard. In these sectors, corruption is present on both sides i.e. on customer and service provider. In one way or other, it hurt the government revenues and user's interest in addition to financial liability for all other users. For example, this study observed that in Pakistan in case of electricity theft/taping/meter tempering, the service provider protects the (user-x) paying monthly bribes and in return allow them to consume unlimited amount of electricity.

This dirty and well-established bribery nexus hurts normal (user-y) in two ways. First service provider will charge him with cost of electricity consumed by (user-x) in form of line losses and detection (forced billing). Second, the area/region that inundated by protected electricity theft and bribery nexus would experience more power breaks. 
According to Jamil and Ahmad (2014), stealing of electricity is a major problem in many countries particularly in emerging countries. Each year service providers lost billions because of theft of electricity form grid system. The problem of stealing is rooted in socioeconomic, political, environmental and technical factors, however, at present service, providers attempt to resolve it only through inadequate technical measures.

There are numerous countries where inadequate and irregular supplies of electricity hamper economic growth; study of Golden and Min (2012) reveals that, Uttar Pradesh India's most populous state electricity theft is substantial in magnitude, since, 10 years.

Furthermore in India, people complains about corrupt practices in departments responsible for services such water and waste management, security, power supply and public transport, housing, overcrowding, slums development (Chand, 2019; Krishnamurthi, 2012).

Problems concerning to services and utilities sectors are overwhelming in Africa, corruption in these sectors results in piles of complaints and corruption cases. According to an estimate, 110 million people in urban areas of Africa are still living without access to electricity; however, these urban areas are nearby to existing power grid infrastructure. According to report 95 million people lives in urban areas of Nigeria, Tanzania, Ghana and most of these urban regions are in close proximity to the grid (Shirley, 2018).

The discussion above can be summarized as; the citizens of emerging countries are suffering from various forms of malafide and corrupt practices of public services and utility sector. For Example in Pakistan almost all services sectors have corruption nexus, some of these are; electric supply companies, natural gas supply companies, water and sewerage management companies, municipalities, primary/secondary education examination boards, etc. However in India and Bangladesh people are suffering from similar problems in addition to mass scale theft of power inappropriate use of government funds, long delays in service performance, pilferage, human right violation in law-enforcing agencies and irresponsible conduct of government functionaries. Whereas in African regions studies shows that, African countries receive huge aid and grants from emerging countries. Nevertheless, overwhelming corruption of government's majority of population in these regionsdo not have accesses to even basic infrastructure and power supply. The summation of problems citizens are facing in emerging countries are listed in Table 1.

\section{Need of Smart City Concept (SCC) and Information Communication Technology (ICT)} applications: In order to ensure transparency and to minimize the level of corruption, this study stress that SSC-ICT implementation will be a viable option to seek the solution for stated problems. Transparency in public offices will help governments to measure progress and identify areas for improvement. However, lack of transparency and citizen empowerment will decline functionality and credibility of governance.

ICT innovations can help make available tools that are hard for humans to tamper with and to enhance communication. For many (though not all) corrupt activities, the corrupt agent needs to somehow evade the rules or procedures that the official government bureaucracy has set up. Technology can help address this problem by ensuring mechanically that certain procedures are followed (Duflo et al., 2012).

Study of Benjamin and Pande (2011) has highlighted the importance of transparency in functionaries of emerging countries. According to their study, transparency is access of citizen to information about government actions. Citizens have right to monitor government officials and enforce greater accountability. According to TI. (2016), emerging countries can successfully curb the corruption through government openness, freedom of the press, transparency and access to information. Access to information increases the responsiveness of government bodies, while simultaneously having a positive effect on the levels of public participation in a country.

Several SCC-ICT models incorporate ICT to address the challenges experiencing by emerging nations. For example, Awad et al. (2017) presented the framework of smart city for Gulf Cooperation Countries (GCC). GCC smart city model has featured the integration of digital technology into the city's core infrastructure systems, build smart buildings, private and public transportation

Table 1: Issues of corruption in public services and utilities sectors

\begin{tabular}{|c|c|c|c|}
\hline Type of reported problem & $\begin{array}{l}\text { Type of public } \\
\text { sector service and utility }\end{array}$ & Management mode & $\begin{array}{l}\text { Vulnerability to } \\
\text { corrupt practice }\end{array}$ \\
\hline Over/forced billing of electricity & Electric supply & Manual reporting & $\sqrt{ }$ \\
\hline Concealing/helping power theft & Electric supply & Manual reporting & $\checkmark$ \\
\hline Water theft/illegal connection & Water supply dept. & Manual reporting & $\checkmark$ \\
\hline Refuse and solid waste collection & Municipalities & Manual reporting & $\checkmark$ \\
\hline Water scarcity & Water supply dept. & Manual reporting & $\checkmark$ \\
\hline Irregular domestic gas supply & Gas regulating dept. & Manual reporting & $\checkmark$ \\
\hline Excess gas billing & Gas regulating dept. & Manual reporting & $\checkmark$ \\
\hline New connection of either domestic/commercial utility & Electric, water and gas supply dept. & Manual application & $\checkmark$ \\
\hline Maintenance requirement on supplier end & Electric, water and gas supply dept. & Manual reporting & $\checkmark$ \\
\hline Public sewerage faults & Water and sewerage dept. & Manual reporting & $\checkmark$ \\
\hline
\end{tabular}


systems, schools, enterprises, public places, utilities and services, etc. and to integrate them into smart urban systems.

Smart city development is highly complex, challenging and context-specific (Estevez et al., 2016). It enhances the government transparency and empowering citizens through ICT applications to request/apply for required work without visiting the various offices, thus, minimizing the risk of corruption. Report of Estevez further stress that ICT applications will bring transparency in work flow and this will help governmental offices to rebuild their credibility. Which is important to Foreign investors but also among citizens. Because economic growth leads to domestic prosperity, more capital is available for development.

Globally speaking, the concept of smart city is gaining more significance. SCC is taken as a customized tool, capable to assist or monitor various city management issues varies from city to city and country to country. The output of system is based on level of city development and desire for improvement, coupled with the resources available to the residents of such cities or countries (Halimi, 2016).

The other aspect of SCC-ICT Model is that this technology could have a substantial impact on corruption reduction by facilitating virtual, transparent and monitored communication (Yang, 2008).

The discussion above revealed that contemporary researchers have realized the importance of using ICT based services delivery system in emerging countries and they stressed to develop an efficient system to improve the service quality of public sector in emerging countries.

Consequently, this research considers that people of emerging countries need the monitoring system for utilities and services cable to ease the workflow and bring end to corrupt practices in public sector. Moreover, the system should be usable for the majority of people without requiring any special skills and hardware.

Therefore, this research considers that emerging an ICT system is right platform to cater the need of people in emerging countries. Such a system can established through mobile technology in emerging world it would be inexpensive, comprehensive in scope and easy to use.

\section{PROPOSED SSC-ICT MODEL TO ENSURE TRANSPARENCY IN UTILITY AND SERVICE SECTOR OF EMERGING COUNTRIES}

This study also revealed that corruption of public services/utility sector is deep rooted and with passing time the functionaries of service sector has developed or adapted the numerous ways to keep the nexus intact and functioning well. Study of Hors (2000) asserted that it is obvious that problem of corruption in the emerging countries cannot be solved simply by applying anti-corruption structures and rules. In order to improve the situation as nationwide strategy, there is a need to introduce a system that can avert the role of functionaries. Induction of ICT system in services sector would allow users or citizens to file their request and get the public service immediately without bribery. The proposed ICT system could be customized as per the services requirements and user's problems.

Reviewing the above stated factual perspective in section III and Table 1, a conversant and thoughtful approach is required to propose the ICT system to minimize the corruption and to bring relief to citizens of emerging countries. A well-organized ICT system for each service and utility is required to address the stated problems.

In addition to transparency in workflow induction of ICT system will also help to achieve efficiency and pave way for long-term establishment of smart city agenda in under emerging countries. Based on the corresponding information from Table 1, this study has proposed the ICT framework as shown in Table 2.

The proposed ICT framework indicates various settings at which ICT system can be inducted in services and utilities sector. In addition, this ICT framework also indicates the resultant impact after induction of ICT system in particular setting of service. Proposed ICT framework constitutes four key factors:

- Describing problems faced by people

- Indicting the required improvement

- Proposing type of ICT system to replace conventional system

- Describes the possible impact after ICT adaptation

Moreover, to understand the ICT system induction in public services and utility sector, following generalized model is proposed for power distribution companies of emerging countries, as shown in Fig. 1.

Model in Fig. 1 is based upon the conditions related to power distribution and consumptions mentioned in Table 1. Model has a capability to be customized both horizontally and vertically to fulfill the conditions and issues of both service provider and users. However, this model is not specified for particular region or country. In following model this research has proposed the smart system at three levels, firstly at problem reporting stage to register the problem to service provider through mobile internet system (mobile application). Secondly induction of smart metering system (replacing conventional manual metering). Thirdly induction of prepaid metering system or online bill payment.

This study considers that following model will minimize the rate of corruption; prevent power theft and helps government to get full revenue of provided service. 


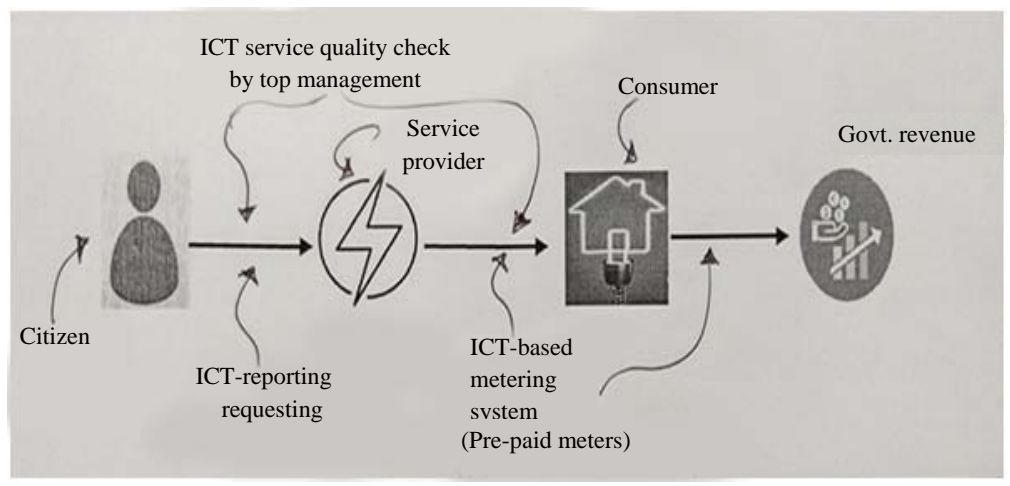

Fig. 1: SSC-ICT Model for power electric power producers and consumers

Table 2: ICT Model to ensure transparency in public services and utility

\begin{tabular}{|c|c|c|c|c|}
\hline Problem & Requirements & SSC-ICT application & Execution & Impact \\
\hline $\begin{array}{l}\text { Over/forced billing } \\
\text { of electricity }\end{array}$ & $\begin{array}{l}\text { Correction as per } \\
\text { consumption on meter }\end{array}$ & Prepaid metering & Mobile application & $\begin{array}{l}\text { No meter tempering-no } \\
\text { human interface }\end{array}$ \\
\hline $\begin{array}{l}\text { Concealing/helping } \\
\text { power theft }\end{array}$ & $\begin{array}{l}\text { To prevent officials } \\
\text { motivated theft }\end{array}$ & Prepaid metering & Mobile application & No organized theft \\
\hline $\begin{array}{l}\text { Water theft/illegal } \\
\text { connection }\end{array}$ & $\begin{array}{l}\text { To prevent functionaries } \\
\text { driven theft }\end{array}$ & Prepaid metering & Mobile application & No organized theft \\
\hline $\begin{array}{l}\text { Refuse and solid } \\
\text { waste collection }\end{array}$ & $\begin{array}{l}\text { Complaining system } \\
\text { works from top to bottom }\end{array}$ & Online reporting system & Mobile application & Hygiene \\
\hline Water scarcity & $\begin{array}{l}\text { Complaining system } \\
\text { works from top to bottom }\end{array}$ & $\begin{array}{l}\text { Online reporting system } \\
\text { smart water supply devices }\end{array}$ & Mobile application & $\begin{array}{l}\text { Water conservation } \\
\text { and regular supply }\end{array}$ \\
\hline $\begin{array}{l}\text { Irregular domestic } \\
\text { gas supply }\end{array}$ & $\begin{array}{l}\text { Complaining system } \\
\text { works from top to bottom }\end{array}$ & $\begin{array}{l}\text { Online reporting system } \\
\text { Smart gas supply devices }\end{array}$ & Mobile application & $\begin{array}{l}\text { Water conservation } \\
\text { and regular supply }\end{array}$ \\
\hline Over gas billing & $\begin{array}{l}\text { Correction as per } \\
\text { consumption on meter }\end{array}$ & Prepaid metering & Mobile application & No organized theft \\
\hline $\begin{array}{l}\text { New connection of } \\
\text { utility/service }\end{array}$ & $\begin{array}{l}\text { Online application and } \\
\text { reporting system }\end{array}$ & Online system & Mobile application & $\begin{array}{l}\text { No human interface-no } \\
\text { corruption }\end{array}$ \\
\hline $\begin{array}{l}\text { Maintenance requirement } \\
\text { on supplier end }\end{array}$ & $\begin{array}{l}\text { Online application and } \\
\text { reporting/accountability } \\
\text { system }\end{array}$ & Online system & Mobile application & $\begin{array}{l}\text { No human interface-no } \\
\text { corruption }\end{array}$ \\
\hline Public sewerage faults & $\begin{array}{l}\text { Online application and } \\
\text { reporting/accountability } \\
\text { system }\end{array}$ & Online system & Mobile application & $\begin{array}{l}\text { No human interface-no } \\
\text { corruption }\end{array}$ \\
\hline
\end{tabular}

\section{CONCLUSION}

A significant finding of this study is that, it highlighted the issues in public services and utility sector for which government functionarie's demands bribes. Although, the scale of corruption is overwhelming in emerging countries however induction of ICT system in services/utility provision structure will minimize the level of corruption and bring relief to citizens.

This study is suggesting induction of ICT system at two levels to ensure potentially positive impacts on the control of corruption. First, establishing or improving online government services and second, developing mobile application for services sector. Services provided through ICT technology will minimize the people in person interaction with functionaries, thus, chance of any possible malafide practices will be avoided.

This study concludes that, after accomplishing the targets of controlling corruption and improving efficiency the system could be gradually, upgraded to (advanced ICT technologies) capable to capture, analyze, share data to prevent, spot and discourage corrupt behavior of functionaries of public service sector.

\section{ACKNOWLEDGEMENT}

Researchers are thankful to Ajman University for providing facilities to complete this study.

\section{REFERENCES}

Awad, J., A. Hyder and A. Irfan, 2017. Development of Smart Cities from Fiction to Reality in Member States of the Gulf Cooperation Council. In: Smart City Networks: Through the Internet of Things, Rassia, S.T. and P.M. Pardalos (Eds.). Springer, Berlin, Germany, ISBN: 978-3-319-613123, pp: 43-63. 
Benjamin, A.O. and R. Pande, 2011. Corruption in developing countries. NBER Working Paper No. 17398, National Bureau of Economic Research, Cambridge, Massachusetts, USA. https:/ideas. repec.org $/ \mathrm{p} / \mathrm{nbr} / \mathrm{nberwo} / 17398$.html

Chand, S., 2019. 11 Major problems of urbanisation in India. Next Generation library, New York, USA. http://www.yourarticlelibrary.com/urbanisation/11major-problems-of-urbanisation-in-india/19880

Desai, R.D., 2018. India continues to rank among most corrupt countries in the world. Forbes Media LLC., New York, USA. https:/www.forbes.com/sites/ ronakdesai/2018/03/07/india-continues-to-be-one-ofthe-most-corrupt-countries-in-the-w orld/\#7eb6 ca $5 \mathrm{f} 79 \mathrm{c} 6$

Duflo, E., R. Hanna and S.P. Ryan, 2012. Incentives work: Getting teachers to come to school. Am. Econ. Rev., 102: 1241-1278.

Estevez, E., N. Lopes and T. Janowski, 2016. Smart sustainable cities: Reconnaissance study. Gdansk University of Technology, Gdansk, Poland. https://mostwiedzy.pl/en/publication/smartsustainable-cities-reconnaissance-study, 139312-1

Fellows, D., J. Leonardo and C. Kortl, 2016. The challenge of public sector corruption. World Policy Institute, New York, USA. https://worldpolicy. org/2016/04/28/the-challenge-of-public-sectorcorruption/

Golden, M. and B. Min, 2012. Theft and loss of electricity in an Indian State. Proceedings of the 2nd International IGC-ISI India Development Policy Conference, December 19-20, 2011, ISIDelhi Center, New Delhi india, pp: 1-38.

Halimi, H., 2016. African smart cities: Potential and Pitfalls. African Centre for Cities, Cape Town, South Africa. https:/www.urbanafrica.net/urban-voices/ african-smart-cities-potential-and-pitfalls/

Hors, I., 2000. Fighting corruption in the developing countries. OECD Observer, Paris, France. http://oecdobserver.org/news/archivestory.php/aid/2 91/Fighting_corruption_in the_emerging\%20_coun tries.html)
Hunt, J., 2007. How corruption hits people when they are down. J. Dev. Econ., 84: 574-589.

Jamil, F. and E. Ahmad, 2014. An empirical study of electricity theft from electricity distribution companies in Pakistan. Pak. Dev. Rev., 53: 239-254.

Khan, F., 2016. Combating corruption in Pakistan. Asian Educ. Dev. Stud., 5: 195-210.

Krishnamurthi, M., 2012. Problems of urban India. Fair Observer, USA. https://www fairobserver. com/region/central_south_asia/problems-urban-india/

Shirley, R., 2018. Millions of urban Africans still don't have electricity: Here's what can be done. The Conversation Media Group Ltd., Melbourne, Australia. https://theconversation.com/millions-ofurban-africans-still-dont-have-electricity-heres-whatcan-be-done-92211

Svensson, J., 2005. Eight questions about corruption. J. Econ. Perspect., 19: 19-42.

TI., 2016. How to stop corruption: 5 key ingredients. Transparency International, Berlin, Germany. https:// www.transparency.org/news/feature/how_to_stop_ corruption_5_key_ingredients

Tanzi, V., 1995. Corruption: Arm's-Length Relationships and Markets. In: The Economics of Organized Crime, Fiorentini, G. and S. Peltzman, (Eds.). Cambridge University Press, Cambridge, UK., pp: 161-180.

Ugaz, J., 2015. Corruption in Africa: 75 million people pay bribes. Transparency International, Berlin, Germany. https:/www.transparency.org/news/ feature/corruption_in_africa_75_million_people_pa y_bribes

WB., 2018. Combating corruption. The World Bank Group, Washington, DC., USA. https://www. worldbank.org/en/topic/gov ernance/brief/anticorruption

Yang, D., 2008. Integrity for hire: An analysis of a widespread customs reform. J. Law Econ., 51: 25-57.

Zamir, M., 2018. The corruption dynamics in Bangladesh. Dhaka Tribune, Dhaka, Bangladesh. https:/www .dhakatribune.com/opinion/op-ed/2018/05/18/thecorruption-dynamics-in-bangladesh 